\title{
Sandflies (Diptera: Psychodidae) associated with opossum nests at urban sites in southeastern Brazil: a risk factor for urban and periurban zoonotic Leishmania transmission?
}

\author{
Andre Antonio Cutolo ${ }^{1 /+}$, Anna Karollina Menezes Teodoro², Fredy Galvis Ovallos ${ }^{3}$, \\ Silmara Marques Allegretti ${ }^{2}$, Eunice Aparecida Bianchi Galati ${ }^{3}$
}

${ }^{1}$ Setor de Controle de Zoonoses e Vetores, Secretaria Municipal de Saúde de Monte Mor, Monte Mor, SP, Brasil ${ }^{2}$ Departamento de Biologia Animal, Instituto de Biologia, Universidade de Campinas, Campinas, SP, Brasil ${ }^{3}$ Departamento de Epidemiologia, Faculdade de Saúde Pública, Universidade de São Paulo, São Paulo, SP, Brasil

Sandflies associated with opossum nests are reported for the first time in the yards of residences located in the urban area of the municipality of Monte Mor, situated in the metropolitan region of Campinas, state of São Paulo, Brazil. Eleven specimens of Evandromyia cortelezzii and one of Evandromyia lenti were captured in two Didelphis albiventris nests. Ev. cortelezzii is considered a secondary vector species for the transmission of Leishmania (Viannia) braziliensis and Leishmania (Leishmania) infantum in the Neotropics. This association may contribute to the introduction, establishment and maintenance of urban and periurban zoonotic transmission outbreaks of Leishmania and should therefore be investigated further.

Key words: reservoir - leishmaniasis - opossum

Opossums (Didelphis sp.) are synanthropic wild small mammals with nocturnal and solitary habits and are commonly found associated with human dwellings due to their search for food and shelter.

Two species of opossum are found in the state of São Paulo (SP): Didelphis aurita (the black-eared opossum), originally an inhabitant of the Atlantic forest and Araucaria forest biomes, and Didelphis albiventris (the white-eared opossum), a species more commonly found in urban centres and in areas of the Caatinga and Cerrado (Brazilian savannah) natural vegetation (Cerqueira \& Tribe 2007).

Leishmania spp, the causative agents of American cutaneous leishmaniasis (ACL) and American visceral leishmaniasis (AVL), have been identified in naturally infected Didelphis sp. specimens in urban and periurban areas of various localities in Brazil (Arias \& Naiff 1981, Sherlock et al. 1984, Cabrera et al. 2003, Carreira et al. 2012, Humberg et al. 2012), including SP (Yoshida et al. 1985). There was $91.6 \%$ infection prevalence among 112 animals examined in the municipality of Bauru, SP, which is an endemic area for AVL (Santiago et al. 2007).

Sandflies are biological vectors of Leishmania. Some species of sandfly are naturally attracted to (Adler et al. 2003) and feed on opossum blood as well as on the blood of human beings and their domestic animals (Dias et al. 2003, Oliveira-Pereira et al. 2008). They are able

doi: $10.1590 / 0074-0276130511$

+ Corresponding author: cutoloandre@yahoo.com

Received 10 February 2013

Accepted 27 November 2013 to transmit Leishmania among these various vertebrate species, connecting wild zoonotic cycles of leishmaniasis with periurban and urban cycles.

This study reports on the presence of sandflies in natural shelters of opossums of the species $D$. albiventris found in residences in the urban environment of the municipality of Monte Mor, in the metropolitan area of Campinas, SP, during the routine activities of the $\mathrm{Mu}-$ nicipal Service for the Control of Zoonoses and Vectors, as the result of requests from the townspeople.

A residence in the district of Nova Alvorada [22 $56^{\circ} 06^{\prime \prime} \mathrm{S} 47^{\circ} 15^{\prime} 02^{\prime \prime} \mathrm{W}, 579 \mathrm{~m}$ above sea level (a.s.1.)] was inspected on 16 September 2010. The animal was found inside a disused wood-burning stove situated on the covered porch of the dwelling. The presence of sandflies was perceived by chance when the animal and the leaves lining its nest were being handled. Three insects were captured on that same day and another eight were captured on the following day.

Another dwelling in the suburb of Paulista (22 $55^{\circ} 58^{\prime \prime} \mathrm{S} 47^{\circ} 16^{\prime} 16^{\prime \prime} \mathrm{W}, 595 \mathrm{~m}$ a.s.l.) was inspected on 22 October 2012. A female opossum was found with eight of her cubs among a heap of bricks under the open sky in the yard of the house. A single sandfly specimen was found when the place was inspected during the removal of the marsupials. In both cases, the females had built their nests from bits of plastic, leaves and/or dry twigs in the yard of the dwellings to protect their cubs that were in one case still in their mother's pouch and in another case outside of it.

The insects were collected manually with the aid of a test tube containing cotton wool soaked in ether or in wide-mouthed plastic bottles. The insects were killed by freezing, clarified, stained, mounted in resin between a coverslip and slide and identified according to Galati (2003). 
The properties on which the opossums were found and the sandflies were captured, although located in an established urban area and bordering paved streets, were located on the edges of neighbourhoods with empty plots, pastures and nearby wooded areas. The second house was located next to a house that had a small chicken coop, from which the opossum was reported to have stolen eggs.

In the former residence, seven males and three females of Evandromyia cortelezzii and a female of Evandromyia lent $i$ were captured. In the latter residence, one female of Ev. cortelezzi was obtained.

$E v$. cortelezzii was reported for the first time in an urban area in association with opossum nests in two human dwellings approximately $2 \mathrm{~km}$ and two years apart.

Although the number of captured Ev. cortelezzii specimens was small, this species is rarely abundant in entomological surveys of sandflies in Brazilian leishmaniasis transmission areas (Oliveira et al. 2003, Souza et al. 2003), but is present in urban areas (Colla-Jacques et al. 2010), and is occasionally the only sandfly species found in this type of locality (Carvalho et al. 2005).

Although it is not considered an important species in the epidemiology of leishmaniases in Brazil, Ev. cortelezzii has aroused scientific interest by virtue of its having been found naturally infected by Leishmania infantum chagasi in an endemic area for ACL in Argentina (Rosa et al. 2012), as in that country it is considered to be the probable secondary vector species both for AVL and ACL (MS 2010).

A survey of previous entomological surveys conducted in the studied area revealed that no other specimens of Ev. cortelezzii or Ev. lenti have been identified among collected sandflies. Nyssomyia neivai was the most abundant species captured in the municipality of Monte Mor, followed by Nyssomyia whitmani, Migonemyia migonei and Pintomyia pessoai (Cutolo et al. 2009), all of which are species associated with the transmission of ACL. $N y$. neivai was also the most abundant species collected in chicken coops, pig pens and dog shelters in a study of human and canine ACL in a rural area of this same municipality, which contained dogs infected with Leishmania braziliensis. Opossums were the most common wild animals captured in the studied area from 2009-2012, with 58 specimens collected in urban and rural areas of the municipality. Of those, 55 were D. albiventris and three were $D$. aurita. One of the $D$. albiventris specimens was found to have Leishmania sp. DNA by means of polymerase chain reaction performed on a biopsied ear skin sample (unpublished data).

The area of AVL incidence in canine and human hosts is undergoing expansion and urbanisation in SP. Although a high infection prevalence $(91.6 \%)$ has been found in Didelphis sp. in the municipality of Bauru (Santiago et al. 2007), the role that wild animals potentially play as L. infantum chagasi reservoirs is still poorly understood in the various Brazilian municipalities that have reported transmission.

The association between sandflies and opossums in urban areas may contribute to the introduction of Leishmania spp as well as to the establishment and mainte- nance of their foci of transmission. The present study is the first report of Ev. cortelezzii and Ev. lenti captured in association with $D$. albiventris burrows in an urban area that demonstrates the affinity of these insects with this host species. The role that these sandfly-Didelphis sp. associations may play in the epidemiology of ACL and AVL prompts further investigation.

\section{REFERENCES}

Adler GH, Becerra MT, Travi B 2003. Feeding success of Lutzomyia evansi (Diptera: Psychodidae) experimentally exposed to small mammal hosts in an endemic focus of Leishmania chagasi in northern Colombia. Biomedica 23: 396-400.

Arias JR, Naiff RD 1981. The principal reservoir host of cutaneous leishmaniasis in the urban areas of Manaus, central Amazon of Brazil. Mem Inst Oswaldo Cruz 76: 279-286.

Cabrera MAA, Paula AA, Camacho LAB, Marzochi MCA, Xavier SC, da Silva AVM, Jansen AM 2003. Canine visceral leishmaniasis in Barra de Guaratiba, Rio de Janeiro, Brazil: assessment of risk factors. Rev Inst Med Trop Sao Paulo 45: 79-83.

Carreira JCA, Silva AVM, Pereira DP, Brazil RP 2012. Natural infection of Didelphis aurita (Mammalia: Marsupialia) with Leishmania infantum in Brazil. Parasit Vectors 5: 111.

Carvalho SMS, Guimarães EM, Souza YB, Braga VB, Vianna LC, Santos PRB, Souza S, Silva R, Pereira A, Leite MH 2005. Primeiro relato de Lutzomyia cortelezzii (Brèthes, 1923) na cidade de Ilhéus, BA. Rev Soc Bras Med Trop 38: 442-443.

Cerqueira R, Tribe CJ 2007. Didelphis. In AL Gardner, Mammals of South America marsupials, xenarthrans, shrews and bats, Vol. 1, The University of Chicago Press, Chicago, p. 17-25.

Colla-Jacques FE, Casanova C, do Prado AP 2010. Study of sand fly fauna in an endemic area of American cutaneous leishmaniasis and canine visceral leishmaniasis in the municipality of Espírito Santo do Pinhal, São Paulo, Brazil. Mem Inst Oswaldo Cruz 105: 208-215.

Cutolo AA, Troncarelli MZ, Machado JG, Luvizotto MCR, Zuben CJV, Langoni H, Giorgio S 2009. Vigilância epidemiológica das leishmanioses no município de Monte Mor, estado de São Paulo, Brasil. Vet Zootec 16: 634-641.

Dias FOP, Lorosa ES, Rebêlo JMM 2003. Fonte alimentar sanguínea e a peridomiciliação de Lutzomyia longipalpis (Lutz \& Neiva, 1912) (Psychodidae, Phlebotominae). Cad Saude Publica 19: 1373-1380.

Galati EAB 2003. Morfologia, terminologia de adultos e identificação dos táxons da América. In EF Rangel, R Lainson, Flebotomíneos do Brasil, Fiocruz, Rio de Janeiro, p. 53-175.

Humberg RM, Oshiro ET, Cruz MSP, Ribolla PE, Alonso DP, Ferreira AM, Bonamigo RA, Tasso Jr N, de Oliveira AG 2012. Leishmania chagasi in opossums (Didelphis albiventris) in an urban area endemic for visceral leishmaniasis, Campo Grande, Brazil. Am J Trop Med Hyg 87: 470-472.

MS - Ministério de Salud Argentina 2010. Leishmaniasis visceral. Guia para el equipo de salud. Available from: msal.gov.ar/images/stories/epidemiologia/pdf/guia-leish.pdf.

Oliveira AG, Andrade Filho JD, Falcão AL, Brazil RP 2003. Estudo de flebotomíneos (Diptera, Psychodidae, Phlebotominae) na zona urbana da cidade de Campo Grande, Mato Grosso do Sul, Brasil, 1999-2000. Cad Saude Publica 19: 933-944.

Oliveira-Pereira YN, Moraes JLP, Lorosa ES, Rebêlo JMM 2008. Preferência alimentar sanguínea de flebotomíneos da Amazônia do Maranhão, Brasil. Cad Saude Publica 24: 2183-2186. 
Rosa J, Pereira DP, Brazil RP, Andrade Filho JD, Salomón O, Szelag E 2012. Natural infection of cortelezzii complex (Diptera: Psychodidae: Phlebotominae) with Leishmania braziliensis in Chaco, Argentina. Acta Trop 123: 128-131.

Santiago MEB, Vasconcelos RO, Fattori KR, Munari DP, Michelin AF, Lima VMF 2007. An investigation of Leishmania spp in Didelphis spp from urban and peri-urban areas in Bauru (São Paulo, Brazil). Vet Parasitol 150: 283-290.

Sherlock IA, Miranda JC, Sadigursky M, Grimaldi Jr G 1984. Natural infection of the opossum Didelphis albiventris (Marsupialia,
Didelphidae) with Leishmania donovani, in Brazil. Mem Inst Oswaldo Cruz 79: 511

Souza MB, Marzochi MCA, Carvalho RW, Ribeiro PC, Pontes CS, Caetano JM, Meira AM 2003. Ausência da Lutzomyia longipalpis em algumas áreas de ocorrência de leishmaniose visceral no município do Rio de Janeiro. Cad Saude Publica 19: 1881-1885.

Yoshida ELA, Silva RL, Cortez Jr LS, Correa FMA 1985. Encontro de espécie do gênero Leishmania em Didelphis marsupialis aurita in São Paulo state, Brazil. Rev Inst Med Trop Sao Paulo 27: 172 . 